\title{
SOME HEAVY METALS RESIDUE IN EDIBLE OFFALS AND MEAT OF NATIVE CATTLE AT ALEXANDRIA GOVERNORATE
}

\author{
Sawsan M. Arafa
}

Anlmal health Institute. Alexandra

\begin{abstract}
Heavy metal residues are considered among the mast important chemical pollutants in food espectally meat and offals which leads to several publlc health hazards .

Thes study was conducted to determine the levels of some heavy metals residue as lead ( $\mathrm{Pb}$ ), cadmium ( $\mathrm{Cd}$ ), copper (CW), zinc $(\mathrm{Zn})$, chromlum $(\mathrm{Cr})$ and mercury $(\mathrm{Hg})$

The residues were determined in 120 sainples of meat and offat samples (20) of each (meat, liver, kidney, heart. spleen and lung) of cattle, the samples were collected from retail stores and butchers at Alexandria govemorate. These samples were analyzed far levels of lead, Cadmium, Copper, zinc. Chromium and mercury by using Atomic Absorption Spectro photometer.

Our results showed that the mean values of lead $(\mathrm{Pb})$ were $0.110,0.320,0.223$. $0.150,0.040$ and 0.004 p.p.m respectively in meat, kidney, liver, heart, spleen and lung. in case af cadmlum (Cd). the concentration of mean values were $0.022,0.038$. $0.022,0.056,0.048$ and 0.066 p.p.m respectluely in the examined samples. Concerning ropper $(\mathrm{C} W$. the mean values were $1.590,2.580,2.100,1.910,2.080$. and 1.300 p.p.m respectively which in case of zinc $(Z n)$ the mean values were ranged from 0.85. to 10.060 p.p.m respectively in the examined samples while the mean values of chromium $[\mathrm{Cr}$ ) were $0.006,0.023,0.030 .0 .040 .0 .002$, and $0.032 \mathrm{p} . \mathrm{p} . \mathrm{m}$ respectively in the exarnincd samples but in case of mercury $(\mathrm{Hg})$, the mean values ranged from 0.081 to 0.340 p.p.m respectively.

From the pervious results, It was reported that most of this studied sainples had levels of heavy metals within the maximum permislble limits with the Egyptian standard except the mean concentration of cadmlum (Cd) with exceeded the (Imit in case of heart and lung samples $(0.056 .0 .066 \mathrm{ug} / \mathrm{g})$ p.p.m respectively .

The public health impartance and toxic effect of these heavy metals as well as suggestive recommendations to minimize polluhon with these heavy metals were discussed.
\end{abstract}

\section{INTRODUCTION}

Nowadays, environmental pollution is considered one of the most important problem af- fecting meat production capacity of grazing anlmal. Metal of envionmental interest include elements that are macronutrients in the 
blosphere (Na.K.Ca) or micronutrients (Fe,Cu. $\mathrm{Zn}$,ete $\mathrm{I}$ and some that have uoknown blologlcal function e.g. ( $\mathrm{Pb} . \mathrm{Cd}$ ) and that are generally regards as toxdc elements. Metalic elements are cumulative toxicant because they are excreted slowly and thelr toxicity depends on their dosage the route. frequency and duration of administration (Under wood 1977 and JECFA2005).

Heavy metals liberated into the environment through the alr, drinklng water, food or countless human made chemieal and products. Hcavy metals enter and accumulate in body tissues via Inhalation, Ingestion and skIn absorption (Pouls, 2005).

Toxlc elements cadmium. lead and mercuгy are widely distributed in the environment since the industrial revolution in the last 50 years. They are frequently found in minute amounts in food (Pouls 2005). Their toxidty depends on their classical form, the dosage. the route, frequency and duration of adminlstration (Underwood 1977 JECFA, 2005). Cadmium is used extensively in the mining and electroplating Industries and is form bone meal fcrtilizers and fungicldes. Cadmlum accumulates in body over many ycars because the body have homeostatic mcchanism to keep cadmium at a constant level (Nasrl A (2006) sources of lead exposure are alr pollutlon, batterles, chemical fertlizers, dust, foods grown around industrial areas. gasolinc. paints. pesticides, soll and tapwater (Osumex. 2006).

Sources of mercury exposure are atr pollution, diuretics (mercural, fungicides, Insecucides, pcsticldes and tapwater, the high amount of mereury entering the food from $1 \mathrm{n}$ dustrial sources (FAO/WHO 200B). the major sources of heavy metals come from agrleultu- ral. Industrial and sewage waskes which may aceumulated in animal tissues and organs causing severe healthy problem to the consumers. Environmental pollution represent a major problem in the world especially in the less developed eountries and Egypt is one of these countries which suffer from biosphere pollution (alr, soll, and water) (Magouz et al 1989].

Cattle offal (liver, kddney, heart, spleen and lung) have a nutritive values as regard of its constituents. So in Egypt. offal represent on the main foods of large part of populations and these offals can be contaminated by heavy mctal as mercury, cadmium, lead, chromlum, copper, Iron and zinc directly or Indirectly through agricultural compound as fertllizer. pesticides. etc. Industrlally through polluted water with wastes discharges of factorles and/or envronmentally by gases from mining or the motor vehicles (WHO. 1994).

Water is a very critical environmental problem facing public health offleial, the greatest volume of waste diseharged the water course is sewage. sewage contains debris wastes, sanitary from domestics baths (Omer et al 2004). chemical analysis of water significant Increase in heavy metal especlally lead. Cadmium, ZInc and Copper and Increase than other trace elements (Radwan and All 2003).

Heavy metals and other trace elements have been considered as a dangerous substanee causing serlous health hazards to human and other llving organisms through progressive Irreversible accumulation in their bodies as a result of a repeat consuming of small amount of these elements (wheaton and Lawson 1985). 
The concentration of toxic elements In animal tissue and organs depends mainly on the dietary concentration of the elements. absorption of this element, thomeostatic control mechanism of the body for the element and the specles of animal involved (Under wood 1977 .

Heavy metals toxicity represent an uncommon yet clinically significant medical condition. If unrecognized or inapproprlately treated. heavy metal. toxicity can result in signiflcant morbidity and mortallty. the most common heavy metals Implicated in acute and for chronie conditions Include lead, arsenlc, cadmium and mereury in non-industrial sttuations, the major souree exposure of huinan and animal to toxic element occurs principally through their food supply (Sunderman. 1998).

So, the present study was to determine the levcls of some heavy metals especlally cadmium. eopper, lead. zlne, chromlum and mercury in meat and orlals of cattle at Nexandrla prownces with their relation to public health and to deteet the safety to human eonsumpthon through companng with the permissible limits and discussed this because there is a few reports were explain the hyglenlc quallty of these offals , and some studles tries to focus some light on the relationshlp between heavy metal pollution $(\mathrm{Hg}, \mathrm{Cd}, \mathrm{Cu}, \mathrm{Zn}, \mathrm{Cr}$. etc) in the oflals and meat (Mangour et al, 1088).

Therefore the objective of the present Investigation was initiated to estimations of chemical quality of meat and native cattle offal (liver, kidney, heart, spleen and lungl with speclal reference to some heavy metals resldue .

\section{MATERIAL AND METHODS}

1- Collection and proparation of samples:

A total of one hundred and twenty samples (20 each of meat, kudney. llver, heart, spleen and lung ) were collected from butcher shops in Alexandria guvemorate. The collected samples were washed with delonized water and separately wrapped in acld washed polyethy. lene bags. Such samples were transferred without delay to the laboratory and then stored in frozen condition at $-20^{\circ} \mathrm{C}$ until analysis was carried out.

\section{2- Analysis of samples :}

a-Digestlon procedure :

Each sample was thoroughly minced and digested aecording to the technique recomrnended by khan et al 1995).

b- Heavy metal analyols ;

Heavy metals including cadinsum. lead. copper, zinc, and chromium were determine In using atomic absorption spectrophotometer (PERKIN ELMEK 2380) according to Rlchard and Rubln Shaplro (1986). In ease of mercury, the analysis was conducted according to Honway and Donny (1985) using flameless atomic absorption spectrophotometer .

\section{Otatlotical analysilo :}

The obtalned data were analyzed statist1cally according to the method recoinmended by Petrle and Watson (1999).

\section{RESULTS}

The heavy metals concentratlons in meat and offals were statistically analyzcd and summarized in table (1) with the recommend permissible limits and with ngures $11,2,3$, 4.5.6) to detect which was highly meat or ed!ble offals in the monltoring of the heavy met- 
als residues, also, there, was a table (2) to evaluate the eorrelation eoeffelent between dilferent organs according to the levels of the examined heavy metals.

\section{DISCUSSION}

It has beeome important to determine the eontent of heavy metals in meat and olfals as an essential part in human dlet, and this elements make up one of the serlous groups of pollutants and this eome from various sources as a result of modern industerzation so, It is necessary to monitor the levels of this metals residuc to evaluatc the acceptability to hurnan consiumption .

Heavy metals or toxje elements are traee elements with density at kast five times that of water as such they are stable clements. they eamot be serious health hazards to human and other living organism ( Wheaton and Lamson 1985). These inelude cadmium (Cd), lcad (Pb), mereury (Hg), copper (Cu), zinc $(\mathrm{Zn})$ and ehromlum $(\mathrm{Cr})$. Human exposure to heavy metals has Hsen dramatically in the last fifteen years and from dally or weekly diet of human is from mcat or oflals so, a toplc of publle hcalth coneern because metals may be concentrated with along time and Icad to be a dangerous level by meat and offals in the human ehaln (Albert 2002, Smith and Tichochine 2002) .

The statical analytical results of heavy metals in cittle meat and its offals lllustrated in table (1) and revealed that the mean values of all samples not exeeed the permissible limit which rccommended by FAO / WHO (1989) and Egyptian organization standardization (1993) except in two samples of heart and lung, we found that the mean values of eadmium (Cd) were $10.056 .0 .66 \mathrm{ug} / g)$ p.p.m re- sistively, these results were nearly similar to these reported by Rablec A. E. (2001) who found that eadmium (Cd) residues in liver. heart of cattle were $0.081,0.063 \mathrm{ug} / \mathrm{g} \mathrm{ppm}$ respeetlvely and also similar to Khan et al (1906) while they were lower than those obtalned by Abdel-Rahman (2004) which the reported result of cd residues in liver. kidney were 6.180 and 5.355 ug/g p.p.m respeetively and also lower than those recorded by EL Atabany (1998) who found that cadmlum (Cd) residues in museles, liver and kldney of cattle were $0.11,0.024$ and 0.38 ug/g p.p.m respectuvely.

Mean while the obtained results were higher than those recorded by Ormima et al (2000) which found that $(\mathrm{Cd})$ residues of liver of cattle was $0.022 \mathrm{ug} / \mathrm{g}$ p.p.m respectively and also the results reported here, lower than that were recorded in livers of Canadian slaughtered cattle and sheep (Ballsubry et al 1991).

\section{Lead Pb :}

The resulted presented in table (1) and IIgure (1) poinled out that the mcan values of lead $(\mathrm{Pb})$ in all examined samples were within P.P.L but was in high average and within permissible limit in kidney sample (0.32) ug/g p.p.m respeetively and the lowest average was In the lung sarnple (0.004 ug/g p.pm) respectively and this result was simjlar to those which oblained by Alaa M. Morshdy et al (2006) found the $\mathrm{pb}$ residue mean value $0.032 \mathrm{ug} / \mathrm{g}$ p.p.m in kidney of camel carcasses and lower than the result obtained by Hassouba and Omima (2007) found lead (Pb) mean value was $0.70 \mathrm{ug} / \mathrm{g}$ p.p.m respectively in meat sample and not agreed with Hala (2004) reported the concentration of $\mathrm{pb}$ in 
muscle of cattle was 1.39 p.p.m respectuvely. Mean whlle, Moura and Bamha (1893) recorded higher lead $(\mathrm{Pb})$ residues in cattle meat. The exposure to lead $(\mathrm{Pb})$ of concern mainly because of possible detrimental effect on intelilgence. Studies on exposure to lead and Intelligence have Indicated an adverse effert of low level lead exposure on new physlological development (WHO, 1994). Food is one of the major sources of lead exposure. the other arc air (mainly lead dust originating from petrol) and drinking water (Ysart at al 2000). Exposure from these three sources should be reduced and can be demonstrated through following up the blood levcls of different Egyptian population. Although industral and agricultural diseharges are the primary souree of lead polsoning In Egypl (ELNabawt et al. 1987) lead is used in many industrial process. lcad paint. lead gasoline and lead arsenate quantities and ehronic lead polsoning is eharacterized by anemia. muscular pain. lead nephropathy and neuropathy of buth central and pertpheral nervous system (Daoud and Rashed 2002).

\section{Cadmium ( Ca) :}

Al the same table (1) and rigure (2) wc can demonstrated that mean value of cadnium was higher In heart and lung samples 10.056 and 0.066) p.p.m respectlvely and exceeded the permsible linnt, this may be due to higher heavy metal environmental pollution which resulting from varlous industrial activities in Alexandria .

This resuil was agreed with J. Lee et al (2007) which detect the accumulation of $\mathrm{Cd}$ In organs of cattle carcasses $10.058,0.060$ p.p.m respectively) (In todney and liver samples) Daoud et al, (1988) determined Cd in 20 eatue slaughtered in Zagazig eity. the ob- tained results revealed that the mean values of $\mathrm{Cd}$ residues in muscles were 0.309 p.p.m wet weight and also the recorded mean concentration of cd were stated by Doganoe (1998) which estumated the concentration in bovine meat was $0.004 \mathrm{mg} / \mathrm{kg}$ wet wcight . Koh et al (1998) recorded that a survey to assess the extend of $\mathrm{Cd}$ accumulation in south Australlan cattle. None of 262 muscle samples assayed contained cd levels above the maximum permitted concentration of 0.2 $\mathrm{mg} / \mathrm{kg}$ wet weight. Avram et al., (2000) re ported that 44 a samples of vartous organs and tissues were collected fron 8 cows older than 5 years in an arca of hcavy Industrial pollution with lead and cadmlum in parLicular. the results evidenced the $(\mathrm{Pb})$ and (Cd) accumulation and concentration markedly exceed maximum admitted limits charaeteriation cumulative chronle intoxication in this area . Miranda et al (2004) detcrmined the levels of (Cd). in ealves from Asturias. the average. concentration in meat was $2.03 \mathrm{ug} /$ g. Korenckova et al. ( 2002 ) determined the occurrenec of heavy metais in 21 cattle slaughtered on agricultural farms. the highest mean level of (Cd). in the muscle $0.126 \mathrm{mg} /$ kg. Cadmium inhiblts essential enzymes in the Krebs cnergy cycle, directly damages nerve cells resulting in hyperaetivity of the nervous system affeets on bones and joints by altering calelum and phosphorous metabolisir contributes to arthrtis, accurnulates in the kddneys resulting in high blood pressure and kidney disease (Zakrzewiska et al 2002).

The hazards of eadrnium as a food contamInanl, this referred to the use of $\mathrm{Cd}$. for several decades in many industral fields, espectally in the production of the paint, plastic and special alloys (Lucisano, 1988). 


\section{Copper (Cu) :}

Concerning in the table (1) and figure (3) showed that the mean values of Copper (Cu) concentrations of all samples was within the permissible limit and the highest copper concentration was dated in kldney $(2.58 \mathrm{ug} / \mathrm{g}$ p.p.m) respectively and the lowest was detected in lung (1.30 ug/g p.p.m) respectlvely. These rcsults are inagreernent with those obtalned by Pouls (2005) which found copper concentration in kidney and muscles $(2.50$ and 1.50 p.p.m respectively and also was nearly agreement with Lars Johem (1982) whilc the resulted recorded in this study were lower than the results oblained by EL-Sherlf (1991). Copper is an essential trace element for man and aninal. In addition to its role in promoting haematopolesis. it is aiso required for normal activty for many enzymes, and copper is normally present in sufficient amounts in forage and feed stuffs but may be used as food supplement where levels in soll are low.

\section{$\operatorname{Zinc}\left(Z_{n}\right)$ :}

Zinc is an essentlal element for human, as being involved in protein synthesis and as a constituent of many metaloenzemes . Relativty low toxictty of zinc coupled with efficient homeostatic control mechantsms make chronIc zinc toxiclty Irom dietary sources as unilkely hazard to men. From tablc (1) and figure (4) showed that the mean value of examined samples within the permissible limit of $\mathrm{Zn}$ and the highcst concentration lound in kidney sample (10.06ppm)and the lowest concentration found in spleen sample is $(0.85 \mathrm{ppm})$ respectively and this was s/milar whth the obtained risults by Thanae A. (1999) which found the mean value concentration of zinc is highest in kidney sample
(13.78 p.p.m) whlle lower result in were reported by Saliebury et al (1991).

Znc is neeessary for normal growth and development in animal and birds. Oral toxicdtion by zinc leads to bloody watery dlarthea. Intense abdominal pain. central nervous systern depression and tremors Falandyz (1993).

Chromiurn (Cr) :

Chromium is an essential nutricnt required for sugar and fat metabolism . insumclent dietary intake of (Cr) leads to signs and symptoms that are similar to those observed for diabetes and cardiovascular diseases (Anderson R. 1997). Food is a major source to chromlum and found in meat, Msh, sea foods and cereals were rich sources but fruits. milk. olls, fats and sugar wcre poor sources of chromium (Brata kos et al, 2002).

At the same table (1) and Igure (6) which demonstrated that the lowest mean valve com centratlon of chromlum $(\mathrm{Cr})$ was found in mcat sample $10.006 \mathrm{ug} / \mathrm{g}$ P.p.m respectively and the highest concentration present in hcarl sample $(0.030 \mathrm{ug} / \mathrm{g}$ p.p.m) respcctively followed by lung sample $(0.032$ ug/g p.p.ni) respectlvely and in liver and kidncy mean values were $\{0.030$ and $0.023 \mathrm{ug} / \mathrm{g}$ p.p.m) re spertivcly and this obtained rcsults were nearly simlar wit those recorded with Thanae. A. (1999) which gives the mean values of (Cr) in liver and kddney wcre 0.028 and 0.030 ug/g p.p.m. These results agreed to certaln extent with those reported by (Reglue et al. 1990).

\section{Mercury ( $\mathbf{~ B ~}$ ) :}

The results presentcd in table (I) and iggure (6) showed thet the mean value of mercury ( $\mathrm{Hg})$ residues was high in heart sample Irom other sample $(0.34 \mathrm{ug} / \mathrm{g}$ p.p.m) respecLively and within the permisible limit and the 
lowest mean was in meat $10.116 \mathrm{mg} / \mathrm{kg}$ p.p.m), this was agreed with Hassouba and Oralma, (2007) which found that mcan values of $\mathrm{hg}$ residues were $0.02 .0 .01 \mathrm{ug} / \mathrm{g}$ p.p.m in meat samples and also agreed with S.K. Pathaka and M.K.Bhoumlk (2007) and in accordance with those reported by Omlma (1995) whlch recorded that mercury was $0.002 \mathrm{ug} / \mathrm{g}$ in beel meat.

In a study of a typical Canadian dict including red meat, organs, poultry and fish are found mcrcury intake which is know to accumulate in aquatic lood chain (Davla and Mertz $w$ 1996).

Mcrcun' toxiclty causes abnommal ncrvous and physical development (fetal and childhood). ancmla, anorexla, blood changes, blindness. blue linc on gums, collus, dcrmattIs, dimleulty chewing and swallowing. headache. hypretension. memory loss. Kidney damage or fallure and nerve damage (Sklbnlenska 2002) Chronic Toxucity which are toxdc signs of gastrolntesunal disturbances and renal dysfunction developed from 43 clays on wards without any mortality. The toxiclty also Induced nephritus and tubular ncphritls. centrllobular, necrosis of liver, mild to moderate nccresis in splcen, Intcsune and lymph nodes. Zenkers degeneration of cardinc musclcs. The kidneys containcd the largest residues of mercury. followed by liver, splecn, intestine. lymph nodc, skeletal muscle, lungs and heart. The intensity of cgtotoxic changes In various organs was proportional to the arnount of mercury accumulated [S.K. Pathak and Bhoumlk 2007) studies of the content of another hcavy metals which found naturally in food in different species for example arsenic and iron whlch vary in toxdclty and bencht in the dlet Buchet et al 1994 and

\section{School et al 1999.}

From table (2) we detected that there was a weak strong correlation ( $r$ ) between different organs according to the lcvels of the examined heavy metals and illustratcd that data from this table revealed that ther was a strong positive correlation betwon the samples for lead (Pb) residue such as betwcen meat. kidney $(r=0.2)$, splecn, lung $(r=0.5)$ and heart, lung $(r=0.04)$ and also there were a weak negative correlatn between examined samples for $(\mathrm{Pb})$ betwecn liver. lung ( $r=-0.12)$ Meal, lung ( $r=-$ $0.13)$, liver, spleen $(r=-0.05)$. kidney heart ( $r=-$ $0.4)$, kidney, liver ( $r=-0.3)$, and meat, liver ( $r=-$ $0.3)$.

And also for cadmium (cd) wc found a strong positive correlation between examincd samples such as between meat. kidney ( $r=$ $0.6)$ meat, heart $(r=0.3)$ and kidney, heart ( $r=$ $0.2)$ and there was a weak negative correlation bctween kidney. lung ( $r=-0.2)$, liver. hcart $(r=-0.2)$ heart, lung ( $r=-0.1)$ and splcen, lung $(r=-0.2)$ all other heavy metals such as $\mathrm{Cu}$. $\mathrm{Zn}, \mathrm{Cr}$ and $\mathrm{Hg}$ had this corrclatlon. Thereforc. from the last discussion we can observe that the accumulation of heavy metal residues in animal organs was ingher than those in meat and this was agreed to the results obtained by Gary P. K. (1992) which proved that mean residues of $\mathrm{cd}, \mathrm{cu}, \mathrm{pb}, \mathrm{Hg}$ and zinc In kidncy, llver, hcart of bull and cow and showed that these trace metals in edlble tissucs of liveslock was higher than those obtalncd in meat and ajso Antoniou et al, 1995 showed that the general. adverse toxlc efrects are cumulatuvc cspeclally in adlposc tissue than In meat. ather effects include off flavour in lood when present at high concentrations and this was relerred to which in devcloping countries. the problems regarding the unhealthy cnviron- 
ment, bad sanitation and problem of poor environment have a negative direct on the health. therefore the present study alms to monitor the levels of some heavy metals in meat and offals to ensure the avallabllity of offals for consumption. so the study of heavy metals in edible oflals has recently become a topic of public health concern because metals such as cd. pb. cu, et may be concentrated to a dangerous level by this offals In human food chain ( Gordon 1986 ).

The variations of $\mathrm{pb}, \mathrm{cd}, \mathrm{cu}, \mathrm{cn}$. zn and $\mathrm{Hg}$ as to be a heavy metal rcsidues concentration among the results and those recorded by other Invesugator are considered logical due to the differences in animal species. stzc localities the analytieal proeedures, season, salinity, habitats as well as environmental pollution (Jehan.R and Abdel Azlz 2002).

In conclusion one can safety that Mercury. Cadmium and Lead are more toxic and not essential to human and constitute the publlc hcalth hazard. These minerals accumulate in meat and organs and therefore thelr levels must be conunualy monitored cspecially in ready to eat one in liver, lung, spleen. kddncy and heart (Gordon 1980).

In general, retalled offal (liver, kidney, etc) showed the highest significant heavy metals concentration and this may be attributed to the excess and contunues exposure of cut surface and contamination through the alr. dustIng and rustung of utensils (Thanae. A 1999) but meat is of low significant concentration than in olfals and this is proved by sinigo (2000), 2alurewsika et al (2002) and Korenkova et al, (2002).

The recommended International codes of hyglene practice for fresh meat and offals and food standard program codex allmestaries commission (CAC) and Egyplan standards showed be followed. Moreover transport in hyglene vehicles adequate chilling and storage of offal. also the persenuvc measures of signincant conccrn intended for minimizing the pollution with resldues of heavy metals in animal ussues (muscles) and organs and those in. clude:

(I) Minimize the use of phosphate and sludge for fertilization as possible and preventing industrlal and agriculture discharges into the surface water.

(2) A void contamination of water surfaccs with industrial waste products.

(3) Pcriodical cxamination of water surface for animal

(4) Regular analysis of meat and offals for heavy metal pollution and their load should bc evaluated according to the international guldelines as a frultful advise. 
$\mathrm{CV}=$ coefficient of varialion SE=standard error $\mathrm{SD}=$ slandard deviation Max=maximum Min=minimum

\begin{tabular}{|c|c|c|c|c|c|c|c|c|}
\hline \multirow{2}{*}{$\begin{array}{l}\text { Heavy } \\
\text { metals }\end{array}$} & \multicolumn{7}{|c|}{ Heavy metal residues mg/kg (p.p.m) } & \multirow{2}{*}{$\begin{array}{l}\text { Permissible limits of } \\
\text { heavy metals in food } \\
\text { FAO / WHO } 1989 \\
\text { EOS (1993) }\end{array}$} \\
\hline & $\begin{array}{l}\text { Examined } \\
\text { samiples }\end{array}$ & min & $\max$ & Mean & SD & $\pm \mathbf{S E}$ & $\mathrm{CV}$ & \\
\hline \multirow{6}{*}{$\begin{array}{l}\text { Lead } \\
(\mathrm{Pb})\end{array}$} & meat & 0.000 & 0.24 & 0.110 & 0.080 & 0.020 & 72.72 & \multirow{6}{*}{1 p.p.m } \\
\hline & kidney & 0.300 & 0.350 & 0.320 & 0.020 & 0.004 & 6.250 & \\
\hline & Liver & 0.000 & $0.4 \overline{10}$ & 0.223 & 0.16 & 0.04 & 7.174 & \\
\hline & heart & 000.0 & 0.42 & 0.19 & 0.15 & 0.030 & 78.94 & \\
\hline & spleen & 0.000 & 0.070 & 0.04 & 0.03 & 0.007 & 75.00 & \\
\hline & lung & 0.000 & 0.009 & 0.004 & 0.003 & 0.000 & 75.00 & \\
\hline \multirow{6}{*}{$\begin{array}{l}\text { Cadmium } \\
\text { (cd) }\end{array}$} & meat & 0.000 & 0.048 & 0.022 & 0.017 & 0.004 & 77.27 & \multirow{6}{*}{$\begin{array}{c}\text { Not exceed } \\
0.04-0.05 \text { p.p.m }\end{array}$} \\
\hline & kidney & 0.010 & 0.061 & 0.038 & 0.016 & 0.004 & 42.10 & \\
\hline & Liver & 0.020 & 0.048 & 0.022 & 0.060 & 0.003 & 272.7 & \\
\hline & heart & 0.000 & 0.30 & 0.056 & 0.06 & 0.010 & 120.0 & \\
\hline & spleen & 0.009 & 0.082 & 0.048 & 0.027 & 0.006 & 56.25 & \\
\hline & lung & 0.030 & 0.089 & 0.066 & 0.018 & 0.004 & 28.4 & \\
\hline \multirow{6}{*}{$\begin{array}{l}\text { Copper } \\
\text { (Cu) }\end{array}$} & meat & 0.800 & 1.800 & 1.590 & 0.230 & 0.052 & $14 . \overline{46}$ & \multirow{6}{*}{3.5 p.p.m } \\
\hline & kidney & 2.300 & 2.900 & 2.580 & 0.200 & 0.170 & 7.751 & \\
\hline & Liver & $1 . \overline{900}$ & 2.300 & 2.100 & 0.150 & 0.030 & 7.142 & \\
\hline & heart & 1.500 & 2.20 & 1.91 & 0.24 & 0.054 & 12.56 & \\
\hline & spleen & 1.900 & 2.810 & 2.080 & 0.200 & 0.040 & 9.615 & \\
\hline & lung & 1.000 & 1.400 & 1.300 & 0.140 & 0.031 & 10.76 & \\
\hline \multirow{6}{*}{$\begin{array}{l}\text { Zinc } \\
(\mathrm{Zn})\end{array}$} & meat & 6.000 & 7.500 & 7.060 & 0.530 & 0.120 & 7.507 & \multirow{6}{*}{40 p.p.m } \\
\hline & kidney & 9.000 & 10.80 & 10.06 & 0.540 & 0.120 & 5.367 & \\
\hline & Liver & 6.600 & 8.900 & 8.074 & 0.850 & 0.030 & 10.52 & \\
\hline & heart & 7.600 & 8.10 & 7.83 & 0.18 & 0.040 & 2.298 & \\
\hline & spleen & 0.780 & 0.910 & 0.857 & 0.050 & 0.010 & 5.834 & \\
\hline & lung & 6.200 & 6.500 & 6.300 & 0.110 & 0.020 & 1.746 & \\
\hline \multirow{6}{*}{$\begin{array}{l}\text { Chromium } \\
\text { (Cr) }\end{array}$} & meat & 0.000 & 0.010 & 0.006 & 0.005 & 0.120 & 83.33 & \multirow{6}{*}{4 p.p.m } \\
\hline & kidney & 0.000 & 0.043 & 0.023 & 0.014 & 0.003 & 60.86 & \\
\hline & Liver & 0.023 & 0.035 & 0.030 & 0.004 & 0.000 & 13.33 & \\
\hline & heart & 0.020 & 0.07 & 0.04 & 0.02 & 0.003 & 50.00 & \\
\hline & spleen & 0.001 & 0.005 & 0.002 & 0.001 & 0.000 & 50.00 & \\
\hline & lung & 0.008 & 0.081 & 0.032 & 0.029 & 0.007 & 90.62 & \\
\hline \multirow{6}{*}{$\begin{array}{l}\text { Mercury } \\
\text { (Hg) }\end{array}$} & meat & 0.700 & 0.169 & $0 . \overline{116}$ & 0.030 & 0.006 & 25.86 & \multirow{6}{*}{0.5 p.p.m } \\
\hline & kidney & 0.060 & 0.350 & 0.230 & 0.110 & 0.020 & 47.82 & \\
\hline & Liver & 0.059 & 0.034 & 0.233 & 0.108 & 0.024 & 46.35 & \\
\hline & heart & 0.130 & 0.49 & 0.34 & 0.13 & 0.029 & 38.23 & \\
\hline & spleen & 0.048 & 0.206 & 0.161 & 0.054 & 0.012 & 33.54 & \\
\hline & lung & 0.030 & 0.186 & 0.081 & 0.050 & 0.011 & 61.72 & \\
\hline
\end{tabular}

FAO : Food and Agriculture Organization

WHO : World Health Organization

EOS : Egyplian Organization for Slandrization

p.p.m : $\mathrm{mg} / \mathrm{kg}$

$(\lg / \mathrm{g})$

Mansoura, Vet. Med. $J$.

Vol. X. No. 2, 2008 
Table (2): Correlation coefficients between (r) different organs according to the levels of the cxamined heavy metals

\begin{tabular}{|c|c|c|c|c|c|c|c|}
\hline \multirow{7}{*}{$\begin{array}{l}\text { Lead } \\
\text { (Pb) }\end{array}$} & & meat & kidney & Liver & heart & spleen & lung \\
\hline & meat & & 0.2 & -0.3 & -0.1 & -0.3 & -0.13 \\
\hline & kidney & & & -0.3 & -0.4 & -0.2 & 0.08 \\
\hline & Liver & & & & -0.03 & -0.05 & -0.12 \\
\hline & heart & & & & & 0.02 & 0.04 \\
\hline & spleen & & & & & & 0.50 \\
\hline & lung & & & -0.1 & -0.3 & & \\
\hline \multirow{6}{*}{$\begin{array}{l}\text { Cadmiunn } \\
\text { (cd) }\end{array}$} & meat & & 0.6 & 0.1 & 0.3 & 0.05 & -0.30 \\
\hline & kidney & & & 0.1 & 0.2 & 0.1 & -0.20 \\
\hline & Liver & & & & -0.2 & -0.2 & 0.02 \\
\hline & heart & & & & & -0.3 & -0.10 \\
\hline & spleen & & & & & & -0.20 \\
\hline & lung & & 0.2 & 0.1 & & -0.3 & \\
\hline \multirow{6}{*}{$\begin{array}{l}\text { Cupper } \\
\text { (Cu) }\end{array}$} & meat & & 0.3 & 0.4 & 0.04 & -0.2 & 0.50 \\
\hline & kidney & & & 0.2 & 0.1 & -0.1 & 0.20 \\
\hline & Liver & & & & -0.001 & 0.1 & 0.70 \\
\hline & heart & & & & & -0.5 & -0.00 \\
\hline & spleen & & & & & & 0.60 \\
\hline & lung & & -0.1 & 0.2 & & -0.3 & \\
\hline \multirow{6}{*}{$\begin{array}{l}\text { Zinc } \\
(\mathrm{Zn})\end{array}$} & meat & & -0.4 & 0.1 & -0.2 & -0.4 & -0.10 \\
\hline & kidney & & & 0.6 & 0.02 & 0.4 & 020 \\
\hline & Liver & & & & 0.1 & 0.1 & -0.00 \\
\hline & heart & & & & & 0.15 & 0.08 \\
\hline & spleen & & & & & & -0.30 \\
\hline & lung & & & 0.1 & & 0.2 & \\
\hline \multirow{6}{*}{$\begin{array}{l}\text { Chroniunn } \\
\text { (Cr) }\end{array}$} & meat & & 0.1 & -0.03 & 0.2 & 0.5 & 0.30 \\
\hline & kidney & & & 0.2 & -0.4 & -0.2 & -0.10 \\
\hline & Liver & & & & 0.1 & -0.05 & 0.30 \\
\hline & heart & & & & & 0.3 & 0.20 \\
\hline & spleen & & & & & & 0.30 \\
\hline & lung & & 0.2 & & 0.1 & & \\
\hline \multirow{6}{*}{$\begin{array}{c}\text { Mercury } \\
\left(\mathrm{Hg}^{\mathrm{g}}\right)\end{array}$} & meat & & 0.4 & 0.4 & 0.4 & 0.5 & 0.60 \\
\hline & kidney & & & 0.4 & 0.7 & 0.5 & 0.10 \\
\hline & Liver & & & & 0.3 & 0.5 & 0.20 \\
\hline & heart & & & & & 0.7 & 0.30 \\
\hline & spleen & & & & & & 0.20 \\
\hline & lung & & & 0.2 & 0.1 & & \\
\hline
\end{tabular}



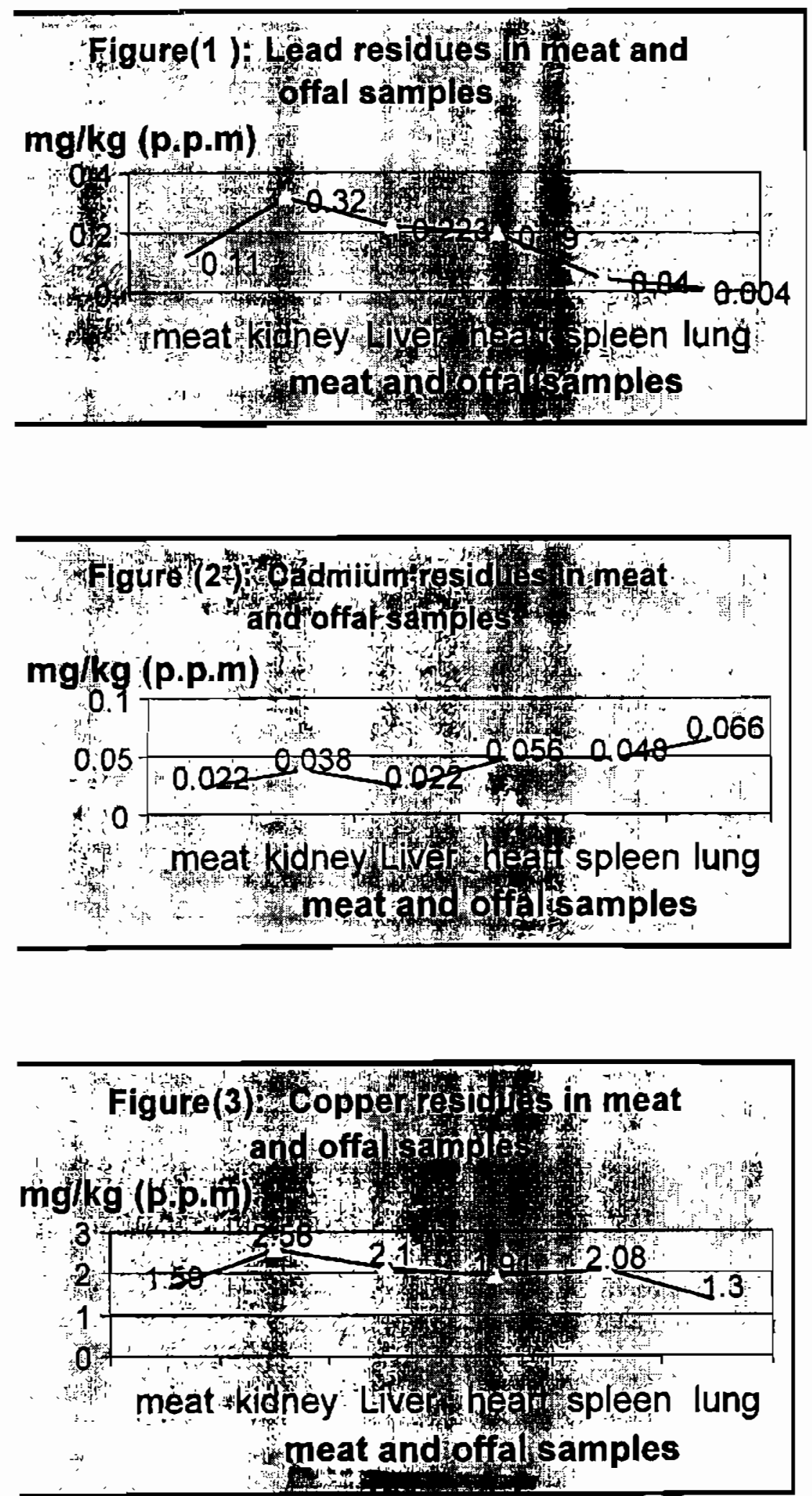

Marsoura, Vet, Med. J.

Vol. X, No. 2, 2008 

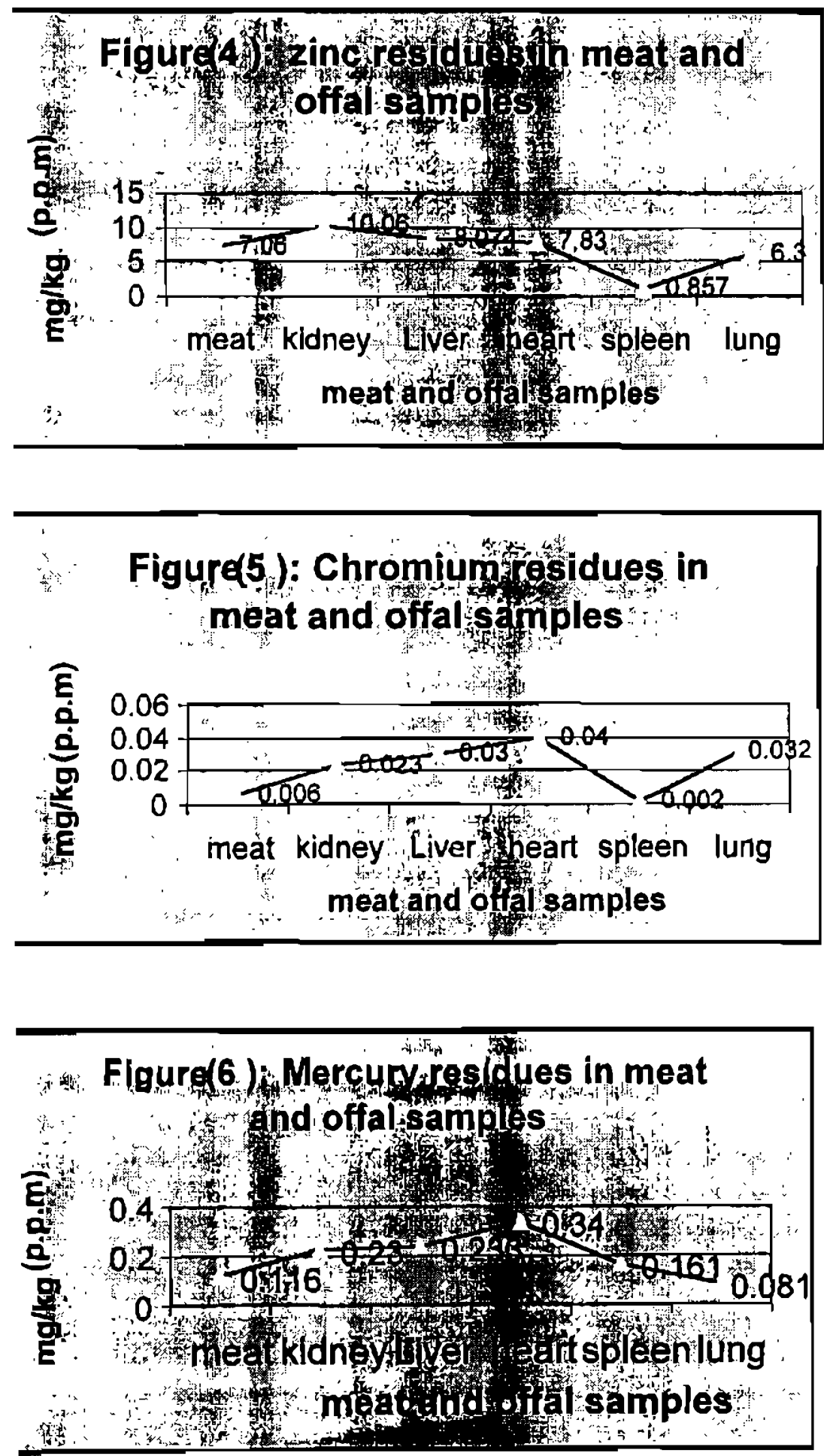

Mansoura, Vet. Med. J.

Vol. X, No. 2, 2008 


\section{REFERENCES}

Abdel-Rahman Ahmed All (2004) : Estlmation of some heavy metals in meat, llver and kidney of sheep drinking water polluted with sewage in some villages of Asslut Governorate. Asslut, Vet.Med.J.Vol, 50 No 102.

Alaa M. Morshdy; Kamel Ebrahlm El-Dosky and F.8.e.L - Sebey (2006) : Some heavy metal residues in camcl carcass. 8th Scl. vet. Med. Zag: conference (Aug. 31-sept.3).

Abertl, Fidanz. A A (2002) : Trace elements in food and meals consumed by students attending the faculty of Califonia Science of total Environment, 15 (1-2) : $133-40$.

Anderson, R.A ( 1987) : Chromlum as an essental nutrient for humen. Regul Toxlcol pharmacol. 26 (1 pt 2) : S35 - 41.

Antonlou, U., Zantopoulos, N. and Tsoukall - papadopoulou K. (1995) : selected heavy metal concentrations in goat liver and kidney vet. Human - toxlcol. 37 (1) : 20-23.

Avram. N.; serdaru, M.; Medrea, N.; Tana sescu, V. and Me hedintu, C. (2000) : Heavy metals accumulation and bio - concentration in the tissues and organs of catthe in areas with heavy metals pollution. studies and researches in veterinary mediclne $8: 83-88$.

Bratokos، M. 8.; Lazos. E. 8. and Bratakos, S. M. (2002) : chromfum content of selected Greek loods , scl Tokal Environ. 6, 290 (1- 3) : $44-58$.

Buchet, J. P.; Paumels، J. and Lauweryı, $R$ (1994) : Assessment of exposure to Inorganlc arsenic foliowing ingestion of marine organlsms by volunteers. Environ Research 66:44-51.
Daoud, J. R. and Rashed, A. Y. (2002) : Determination of somc hcavy metals conc. In Ostrich, turkcy and rabbits tissues in relaton to polluted Watcr. J. Egypt. vct. Med. Assoc . 62 (6A) 205-216.

Daoud, J. R.; Kamel $A$ A and Moustafa, $A$ R. (1998) : Determination of lead, cadmluin and copper resldues in muscles, liver and kidneys of slaughtered cattles and sheep in El-Sharkla Governorate. vet. Med. J . Glza 46 (4A) : 339 - 348 5th sclenufflc congress. fac. vet. Med; Calro universlty .

Davis, G. K. and Mertz, W. (1996) : trace elements in Human and animal nutrition, $5^{\text {th }}$ ed, vol . 1. pp 301-364 new York : Academle press .

Doganoc, D. Z. (1996) : Lead and eadmium concentration in meat. Itver and Kldney of sloventan cattle and plgs from 1989 to 1993. Food Addit contam fcb. Mar: 13 (2):237- 241 .

Egyptlan Organlzation for Standrization and Guality control (1993) : Maximum level for heavy metal contamination in food. ESN 2360.

EL-Atabany, I, A (1895) : cadmlum and lead resldues in some food animals and fish tissues at Marzala, Dakalia, Zaggazig vet. J., 23 (5) : 90.

EL-Nabawi, A G.: Helnzow, B. and Kruse, H. (1987) : AS, Cd. Cu. $\mathrm{Pb}, \mathrm{Hg}$ and $\mathrm{Zn}$ in fish from the Alexandria region. Egypt. Bull. Envion. contam. Toxdcd . 39 : 889 .

EL - Sherff, A.A.6. (1991) : Lead levels in macro and micro environment of cattle at Asslut Governorate. M.V.SC. Thesis faculty of vet. Med.. Assuit Unlversity. Egypt.

Falandys z. J. (1993) : Some toxic and es- 
sential traee metals in eattle from the northern part of Poland. Sel total Environ $-15: 136(1-2): 177-91$.

FAO/WHO (1989) : Joint expert Commlttee on lood additives (WHO) . Teehnical Report Sertes No . 778 (1989) . Evaluation of eercaln food additives and contaminants, Genera.

FAO/WHO (2008) : Evaluation of mercury. lead, eadmium and the food additlves amoronth. direcarbonate and acetyl gallate. WHO lood Additives serles NO 4. Pp.11-56 world Health organization. Geneva .

Gary P. K. Oppenaal (1992) : Bull. cow (meat kidncy), liver (Tracc metals cd, cu. pb, lron and zinc in Edible tlssues of livestock and poultry. Journal of AOAC Intcrnational vol. 75. No 4 .

Gordon, D. T. (1988) : Minerals in sea food quality determination proceeling of the international symposiumon seafood quality dctermination. Alaska. pp. 517-542.

Hala, S. T. (2004) : Heavy metals in bccf and bulfaloes car cases ph. D. Thesis. Meat Hyglene Faeulty of veterinary Medicine. Cairo University .

Hassouba , M.M. and OMAIMA, M.EL. TAHER Lablb Maghraby (2007): Detection of some heavy metals resldues in chilled loeal and Imported (Sudanese) beef. J , Egypt . vet . med . Asso 64, no.2 : 325 - 333

Honway Lolve, Danny Co. (1985) : Digestion of food samples for total mercury determination. Joumal of assoclation of offlcla analyucal chemistry (68) (5): 891-892 .

JECFA (2005) : Jolnt Expert committee on Food Additives www.leh.gov.bk.salelood/ report/heavymetal / heavymetalsum.html $(1-3)$.

Jehan. R. Daoud and A H. Br ABD - EL -
Azl2 (2002) : Determinatlon of Some heavy metal residuesin salted and smoked nshes vet . Med. J., Giza vol. 50. No . 4, 547-557.

J. Lee; J. R. Rounce; A. D. Mackay and N. D. G. Race (2007) : Aceumulation of eadmlum with time in Romney sheep grazing ryegrass - white Clover pasture and soll intake. Australlan Journal or Agrleultural Research . 12:15 AM .

Khan, A T,; Diffay, B. C.; Datir, B. C.: Forester, D. M.; Thompson S. J. and Mlelke, H. W. (1985) : Heavy meats Inllvers and kidneys of goad in Alabama Bull. Environ contam. toxled. 55: 568-573.

Koh, T. S.; Bansemer, P. C. and Frengham, A B. (1988) : Asurvey of the cadmlum concentration in kidney. liver and muscle of south Australlan eattle. Australian $\mathrm{J}$. Experimental Agriculture 38 (6) : 535-540

Korenkova, B.; Skallcha, M; and Nad, P. (2002) : concentration of some heavy metals in cattle reared in the vicinity of a metallurglc industry . Veterinarski Arhir 7295 : $259-267$

Lars. Jorhem (1892) : Determination of Metals in food stuffs by atomic Absorption spectrometry after dry Ashing (cd, zn, cu, Iron, cr I Swedish National food administration po Box 622,S-M51 - 26.

Luclsano, A (1989) : Inqulnamento da Imprenditorla industral Imetalli pesanti. Atti della Soeleta Itallana delle sclenze Veternary, XI III, 85 - 98 .

Magoux, F. I., AAEL - Gamal : M. M. EL Telbang., M. E. Hammed and $M$. F. Balem (1996) : Elfeet of some heavy metals on growth performance and ehromo somal behaviour of blue tilapia (Oerochromis aureus). Food bome eontamination and Egyp- 
thans health. unlversity of Mansoura. Nov. $26-27$.

Mansour, N. K.; Yaslen, N. A. Darwish, A M. and Hamdy, M. M. (1988) : Freezing and microblological quatity of imported frozen bovine livers .

Miranda, M.; Alonsao, M. L.; Cestlllo, C.; Hernandex, J. and Benedi To, J. L. (2004) : Cadmium levelsin llver, kidney and meat In calves from Asturlas (North spa(n). European food Rescarch and Technology 212 (4) : 126-430 .

Mousa, M. M. and 8amaha, I. A. (1993) : Cadmlum. Copper. lead and zinc in carcasses of rood animals. Alex . J. vet scl ., $9(3): 127-131$.

Nasri, A. (2006) : Heavy metals, sources, symptoms, testing and treatment. www.nasrichelation.com/pagcs/treatment /heavy metals.html/(1-5)

Omer, A A M.; Ibrahlm, M. S; EL-Haddad. A. A and All, M. H. M. (2004) : Environmental consequences of the improper land appllcation of sewage waste water disposal Sohag. Egypt: Soll and Ground water pollution . the Sec. Int . conf . for develop and the envir. In the Arab world, March 23-25 Assiut. Egypt

Omlma, D. (1998) : chemlcal constituents of beef, buffaloed and camel's meat ph. D vet thesis. Faculty of vet. med., Calro unlversity. Egypt .

Omlma, M.; Dlab, Abd-El-Azlz, Hashim, $M$. P. and Insberah Kh. Mlra (2000) : Monltoring of hcavy metals Residues in livers of cattle, camcl and sheep.

Osumex (2006) : Lead, Number 82 on the perodic tablet of elements www.heavymetals. test.com/lcad.php(1-4).

Petrl, A. A. and Watson, P. (1999) : Statis- tics for veternary and Anlmal sclence 1 st . Ed . 90-99 the Black well Science Ltd., United KIngdom .

Pouls, M. (2008) : Extended health. A web site for doctors and health profosional. A1 / Meat - 10 htm (1-25)

Rabice A. E. (2001) : Chemical residues in food animals ph.D. Alex. University.

Radwan, M. E. and All. A A. (2003) : Elfect or Sewage Water pollution on some blochemical parameters in sheep in Assiut Govemorate Benl Suef vet. Med. J: XJII (1) : 339-347.

Regius - Moesenyl, A. Anke, M. and ELGandy, H. (10日0): The mineral status of ruminants II. Cu, $2 \mathrm{n}$, and $\mathrm{Mn}$ contents of feed stufts and animal organs Acta Agronomica Hungart ca $39: 155 \cdot 166$.

Richard, P. and Rubln Shaplro, M. (1986) : Determination of trace element in foods by hydrochloric, nitric acid leaching and name atomic absorption spectroscopy . Journal of AOAC .Int: 19 (5) : 868-870 .

Salisbury, D. C.i chan, W. and Sachenbrecker, P. W. (1991) : Multielement concentrations in liver and kudney lissues from nve species of Canadian slaughter animals. J. A.O.A.C.74( 4$): 587-591$.

Schoof, R. A; Yost, L. J.: Elckhoff, E.A. Crecellus, E . A ., Cragin, D, W., MeachCr, D. M. and Menzel, D. B. (1999) : Amarket basket survey of inorganlc arsenic food. Food and chemlcal Ttoxjcology . 37 : 839 - 846.

SInigo, J. G. K. and Doganoc, D, Z. (2000) : Contamination of farm animals and nshes from Slovenla with heavy metals and sulfonamides. Bulletin of Environ. Contamln. And Toxlc 64(2) : 235-241 .

Sklbnelwska, N. A. (2002) : Estimation of 
Iron. copper, zinc and many elements from dupticated dicts provided by hosp tals in Poland Food AddItlves and contamination $19(10): 969-973$

8. K. Pathak. and M. K. Bhowmik (2007) : Chronic mereury toxdcity In goats by administrating mereuric chlordde. Bengal University of Animal and FIshery Sclenees. 37 Kshudiram indla.

Smithe. and Tichochlne (2002) : Environmental nickel pollution: does it protect nickel allergy Journal of statistics. 2nd editon. Mc Graw -Hill New York . 14

Sunderman, F. W. (1998) : Teratogenlcity and emberyotoxicity of melals in human and Experimental animals. Metal Ions in Blology and Mediesne. 5:27-279.

Thanae A. Sekeek (1999) : Hyglenle Quality of imported and native eattle edible offals with special reference to some heay metal residues. Alex. J. Vet. sci vol . $15 \mathrm{~N} 0.5$ October 1999.
Under rood, E. J. (1977) : Trace elements in human and anlmal 4th Ed. Academic press. New York.

Wheaton, F. W. and Lowson, T. B. ( 1880 ) : processing of aquatic food products. Awirely Interscience Publication p.231 232. Jhon Weily and sens., New York. Toronto .

WHO (1994) : Environmental Health crtterin No. 134, WHO Geneva .

Ygart, G.; Mlller, P.; Croasdale. M.; Crews, H.; Robb, P.; Baxter, M.; de L'Argy C. and Harricon, N. (2000) : Total diet study - dielary exposures to aluminum, arsenic. cadmlum, ehromlum, copper, lead, mercury. nickel. Selenium, tin and Zlnc. Food Additlves and eontaminants. 17 (9) : 775 . 786.

Zakrzewloka, M., Blatonska, D, and 8awIcka Kapusta. K. (2002) : cadmlum aceumulation in retus and plaeenta of bankvoles . Bull Environ. contam. Toxicol 169 : 829-834. 


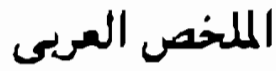

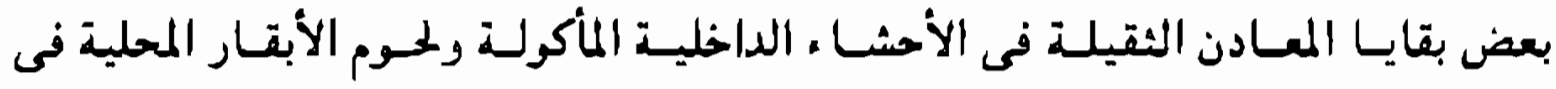

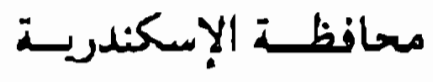

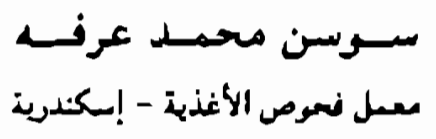

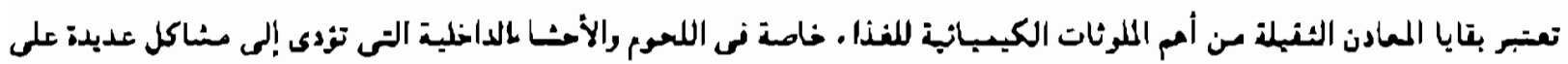

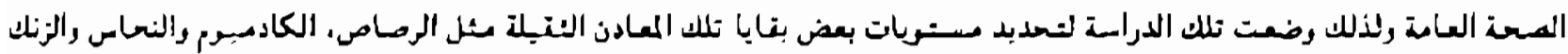
رالكرومرم والزئق.

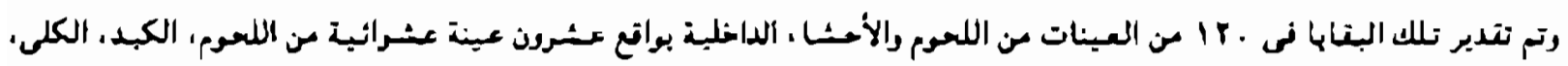

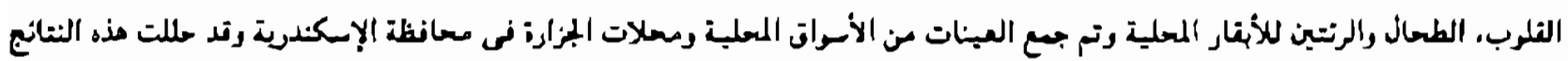

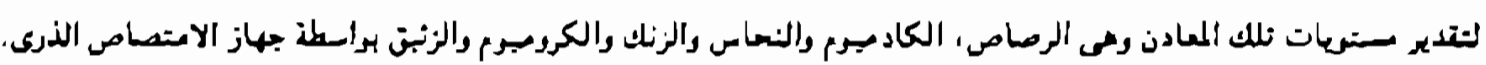

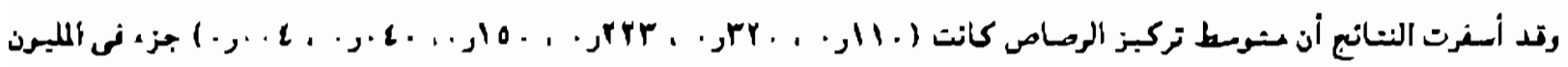

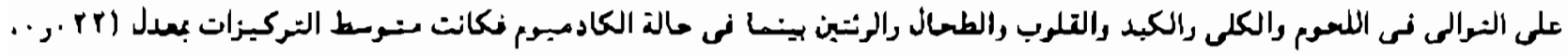

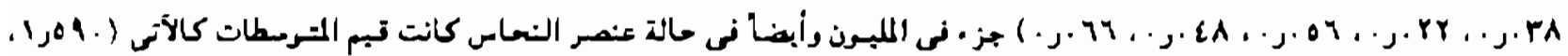

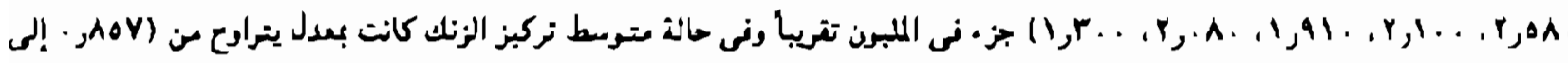

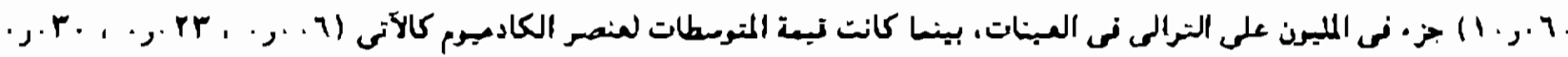

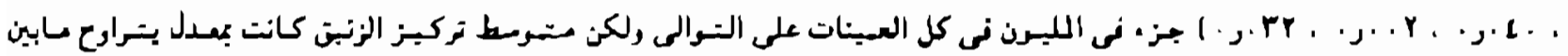

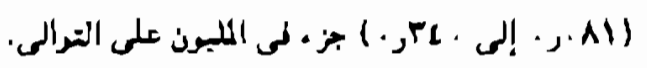

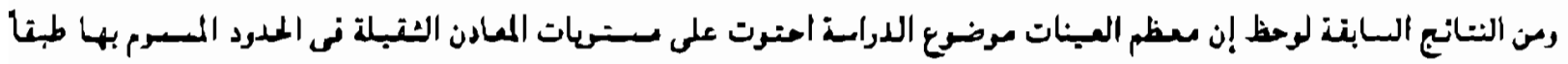

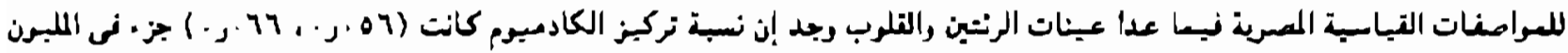

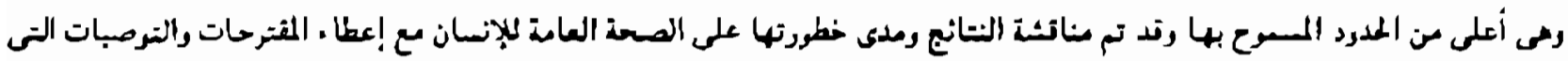
نقلال من مدى تلرثها.

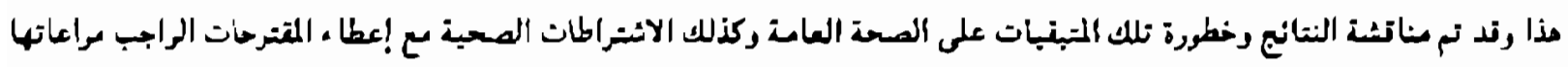

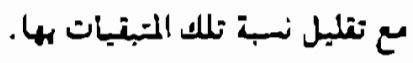

